
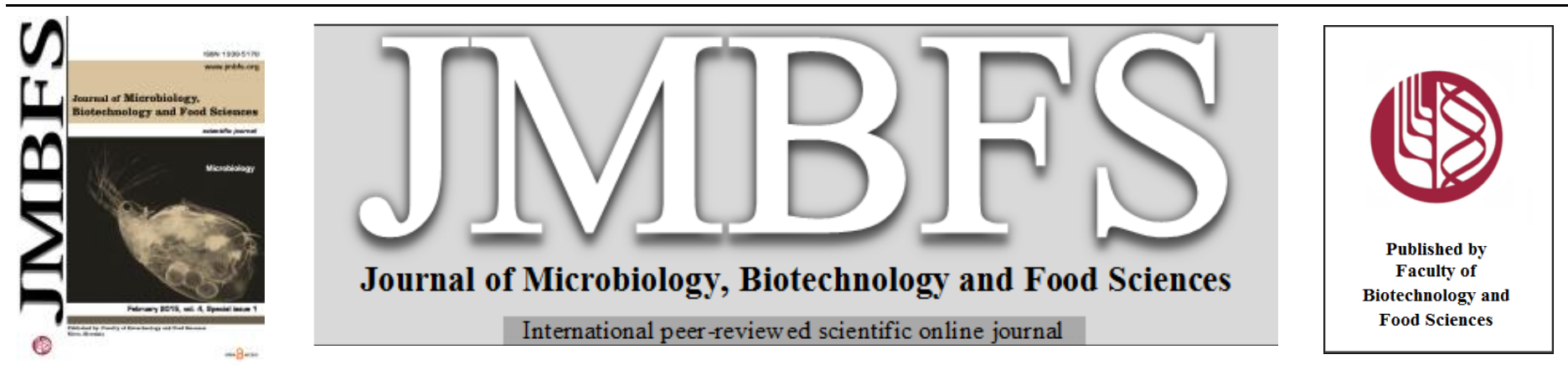

\title{
BACTERIAL MICROFLORA OF FRESHWATER FISH ORIGINATED FROM USMAS LAKE IN LATVIA
}

\section{Margarita Terentjeva ${ }^{*},{ }^{1}$ Inga Eizenberga ${ }^{2}$, Aleksandr Novoslavskij ${ }^{3}$, Vita Strazdiņa ${ }^{2}$, Olga Valciņa ${ }^{2}$, Jevgēnija Ošmjana ${ }^{2}$, Aivars Bērzinšs $\check{L}^{1,2}$}

\author{
Address(es): \\ ${ }^{1}$ Latvia University of Agriculture, Faculty of Veterinary Medicine, Institute of Food and Environmental Hygiene, Helmaña iela 8, LV 3004, Jelgava, Latvia. \\ ${ }^{2}$ Institute of Food Safety, Animal Health and Environment „BIOR“ Lejupes iela 3, Rīga, LV-1076, Latvia. \\ ${ }^{3}$ Lithuanian University of Health Sciences/ Lithuanian Veterinary Academy, Tilžès street 18, 47181 Kaunas, Lithuania.
}

*Corresponding author: Margarita.Terentjeva@1lu.lv

doi: 10.15414/jmbfs.2015.4.ispecial1.74-77

\section{ARTICLE INFO}

Received 8.11. 2014

Revised 16. 12. 2014

Accepted 24. 12. 2014

Published 2. 2. 2015

Regular article

open 2 access

\begin{abstract}
The aim of the present study was to evaluate the bacterial contamination of gills, skin and content of gastrointestinal tract of freshwater fish. Altogether 31 fish samples, including European eel $(n=11)$, Silver bream $(n=3)$ and European perch $(n=17)$ were collected between April and July in 2014 from Usmas lake located in West part of Latvia. For evaluation of bacterial load the number of TBC (total bacterial count) and Enterobacteriaceae genera in gills, skin and intestinal tract was enumerated. Presence of Salmonella spp., $L$. monocytogenes and $Y$. enterocolitica was analyzed according to the ISO methods. Among different fish species investigated TBC in gills, skin and intestinal samples ranged from 1.89 to $7.47 \log$ CFU.g ${ }^{-1}$, from 0.66 to $8.47 \log$ CFU.cm ${ }^{-2}$ and from 0.30 to $8.25 \log$ CFU. ${ }^{-1}$ accordingly. Number of Enterobacteriaceae genera in gills, skin and intestinal tract ranged from 0.7 to $5.78 \log$ CFU.g ${ }^{-1}$, from 4.91 to $7.12 \log$ CFU.cm ${ }^{-2}$ and from 0.70 to $7.47 \log$ CFU.g ${ }^{-1}$, respectively. Number of TBC and Enterobacteriaceae in European eel samples of gills, skin and intestinal tract was significantly less than in Silver bream and European perch samples $(\mathrm{P}<0.05)$. Salmonella and Y. enterocolitica were not found in fish, while L. monocytogenes was isolated from one perch $(1 / 17 / 6)$. Results of study indicate that microbiological quality of eel was better than of perch and bream, which found to be extensively contaminated with TBC and Enterobacteriaceae making fish unacceptable for human consumption. Presence of L. monocytogenes in perch exhibits public health concerns, indicating that fish could be a vector for transmission of pathogen to consumers.
\end{abstract}

Keywords: Freshwater fish, Salmonella, L. monocytogenes, Y. enterocolitica, Enterobacteriaceae, Total bacterial count, Latvia

\section{INTRODUCTION}

Fish meat is a significant part of diet of consumers in Latvia and average consumption of fish per capita was $6.6 \mathrm{~kg}$ in 2013 (Latvijas statistika, 2013) Freshwater fish comprise the important part of total fish and fish products available on market, because of the widespread occurrence in environment Recreational fishing is very popular in Latvia, there fishermen use self-catched fish for meal preparation and this is a specific pattern of consumption of fish. Since recreational fishing for consumption is common among the inhabitants the microbiological assessment of freshwater fish is necessary to get information about fish are available for fishermen for consumption.

Fish microbiological contamination depends on the status of water source. Microflora of surfaces and skin of fish are continuously affected by aquatic environment including bacteria present in water, sediment and contamination from polluted wastewater. Since the changes in microflora of surrounding environment have an impact on number and composition of bacterial microflora fish may serve as the indicator of pollution of aquatic environment (Ribeiro et al., 2010). Despite of this the evaluation of microbiological quality of fish should address not only environmental health aspect, but also the consumers' safety. The environment health and water hygiene may be affected by various factors, e.g. human and animal wastewater or weather condition resulting in contamination of freshwater source and fish with pathogens of public health significance as Salmonella, Listeria and Yersinia and leading to alteration of bacterial microflora of it. Consumption of contaminated fish and fish products can be potentially hazardous to consumers and lead to foodborne infections thus, the prevalence of pathogens in fish raise concerns about product safety issues (Miettinen and Wirtanen, 2006, Junior et al., 2014).

Limited studies on bacterial contamination of fish and the occurrence of pathogens are available on freshwater fish and usually they are covering limited geographical area (Davies et al., 2001, Yücel and Balci, 2010). Such studies are very valuable to identify the problem and to implement the preventive measures among consumers, retailers and fishermen. Previous studies also mostly were more focused on retail, but not fishermen level, so it is valuable to estimate the situation on freshly caught fish obtained from fishermen to recognize the situation at the beginning of a food chain.

Therefore, the aim of the present study was to detect Total Bacterial Count (TBC) and Enterobacteriaceae in fish skin, gills and gut and to evaluate the presence of Salmonella spp., Y. enterocolitica and L. monocytogenes on freshly caught fish samples obtained from fishermen.

\section{MATERIAL AND METHODS}

\section{Selection of samples}

All samples were obtained from Usmas lake located in West part of Latvia during April, 30 to July, 30 in 2014. During sampling water temperature of lake was from $11.8^{\circ} \mathrm{C}$ up to $19.6^{\circ} \mathrm{C}$ (Latvijas vides, geologijas un meteoroloǵijas centrs, 2014) Altogether, 31 fish samples were collected, including 11 samples of European eel (Anguilla anguilla) and 3 and 17 samples of silver bream (Blicca bjoerkna) and European perch (Perca fluvialitis), respectively. Samples were obtained directly from fishermen, put in sterile bag and transported to the laboratory on ice immediately after sampling. Testing was initiated within 2 hours after collection of samples.

\section{Sampling}

For detection of TBC and Enterobacteriaceae genera skin, gill and intestinal tract samples were investigated separately. Surface samples of fish skin were collected with abrasive sponge moisturized with $0.1 \%$ peptone water by covering a $25 \mathrm{~cm}^{2}$ or $100 \mathrm{~cm}^{2}$ area of fish skin depending on fish size. For collection of intestinal tract samples the abdomen was incised and the intestinal tract containing both the intestines with the content was separated from surrounding tissues. For gill sampling the gills were aseptically separated from surrounding tissues. Skin, gills and intestinal tract of each fish were investigated separately and not less than $1 \mathrm{~g}$ 
of gills and intestinal tract and a sponge covering $25 \mathrm{~cm}^{2}$ of skin were used for testing.

Samples for detection of Salmonella spp. L. monocytogenes and Y. enterocolitica were prepared with pooled sample of skin, musculature and intestinal tract of each fish. In total $25 \mathrm{~g}$ of material was used for detection of each pathogen.

\section{Bacteriological analyses}

For detection of TBC and Enterobacteriaceae $0.1 \%$ peptone water was added to each gill, skin and intestinal tract sample to make a 1:10 dilution. After this the serial dilutions were prepared for the investigation of samples. For TBC $1 \mathrm{ml}$ of each serial dilution was transferred onto plate count agar (PCA, Biolife, Milan, Italy) using two plates for each dilution, and incubated for $72 \mathrm{~h}$ at $30^{\circ} \mathrm{C}$. After incubation bacterial colonies were enumerated

For detection of Enterobacteriaceae $1 \mathrm{ml}$ of suspension from each serial dilution was transferred onto violet-red bile glucose agar (VRBA, Biolife) using two plates for each dilution and incubated for $24 \mathrm{~h}$ at $37^{\circ} \mathrm{C}$. Typical colonies of Enterobacteriaceae were tested from oxidase activity and inoculated into Glucose agar (Biolife) with subsequent incubation for $24 \mathrm{~h}$ at $37^{\circ} \mathrm{C}$. Only oxidase negative and glucose positive colonies were confirmed as Enterobacteriaceae. For Enterobacteriaceae count typical bacterial colonies were enumerated.

For detection of Salmonella a total amount of $25 \mathrm{~g}$ of fish samples were transferred into $225 \mathrm{ml}$ of buffered peptone water and incubated for $18 \pm 2 \mathrm{~h}$ at $37^{\circ} \mathrm{C}$. After pre-enrichment $0.1 \mathrm{ml}$ of suspension was transferred in RappaportVassiliadis broth (Biolife) and Mueller-Kauffmann Tetrathionate-Novobiocin broth (Biolife) for enrichment for $24 \mathrm{~h}$ at $41.5^{\circ} \mathrm{C}$ and $37^{\circ} \mathrm{C}$ accordingly. Enriched suspension was plated out onto brilliant green (Biolife) and XLD (Biolife) aga for subsequent incubation for $24 \mathrm{~h}$ at $37^{\circ} \mathrm{C}$ and plates were examined for the presence of presumptive colonies.

For detection of L. monocytogenes an amount of $25 \mathrm{~g}$ of sample was transferred into Half-Fraser broth and incubated for $24 \mathrm{~h}$ at $30^{\circ} \mathrm{C}$. After incubation $0.1 \mathrm{ml}$ of suspension was transferred into Fraser broth and incubated for $48 \mathrm{~h}$ at $37^{\circ} \mathrm{C}$. An amount of $0.1 \mathrm{ml}$ of enriched material of Half-Fraser and Fraser broth was plated out on Oxford (Biolife) and ALOA (Biolife) agar plates and incubated for 24-48 $\mathrm{h}$ at $37^{\circ} \mathrm{C}$. After incubation agar plates were screened for the presence of presumptive colonies, which were selected for further confirmation. Presumptive colonies were stained according to Gram, checked for catalase activity, mobility and $\beta$-hemolysis. Suspicious Listeria spp. isolates were confirmed with API Listeria (BioMérieux, France).

For detection of Yersinia spp. an amount of $25 \mathrm{~g}$ of sample was transferred into peptone sorbitol bile salt broth and incubated $24 \mathrm{~h}$ at $22^{\circ} \mathrm{C}$. After incubation 0.1 $\mathrm{ml}$ of suspension was plated out onto CIN agar (Biolife) with and without treatment with $0.5 \% \mathrm{KOH}$ prior to plating. CIN plates were incubated at $30^{\circ} \mathrm{C}$ for 24-48 $\mathrm{h}$ and examined for the presence of typical colonies after incubation. Selected colonies were screened for oxidase activity and urea hydrolysis and oxidase activity negative and urea hydrolysis positive cultures were confirmed with API 20E (BioMérieux, France)

\section{Statistical analyses}

All microbial counts data were transformed to decimal logarithms. For evaluation of differences between means of microbial counts for TBC and Enterobacteriaceae genera in ell, bream and perch samples a Student's $t$ test analysis was applied.

\section{RESULTS AND DISCUSSION}

Among different fish species investigated TBC in gills ranged from 1.89 to 7.47 $\log$ CFU. $\mathrm{g}^{-1}$ and the highest number of TBC was observed in Silver bream gill samples, while the lowest - on eels gill samples. Number of TBC was the highest in silver bream and the lowest in ell in intestinal samples too and ranged from 0.30 up to $8.25 \log$ CFU. $\mathrm{g}^{-1}$. TBC in skin samples ranged from 0.66 up to 8.47 $\log$ CFU. $\mathrm{cm}^{-2}$, there the highest number of TBC was originated from European perch samples, while the lowest from eel samples (Table 1).

Table 1 The total bacterial count (TBC) in freshwater fish gills, skin and intestinal tract

\begin{tabular}{|c|c|c|c|c|c|c|}
\hline \multirow{3}{*}{ Fish species } & \multicolumn{6}{|l|}{ Sampling site } \\
\hline & \multicolumn{2}{|c|}{ Gills } & \multicolumn{2}{|c|}{ Skin } & \multicolumn{2}{|c|}{ Intestinal tract } \\
\hline & Mean \pm SD $^{d}$ & Range & Mean \pm SD & Range & Mean \pm SD & Range \\
\hline $\begin{array}{l}\text { European eel } \\
\text { (Anguilla anguilla) }\end{array}$ & $2.41 \pm 0.51^{\mathrm{a}}$ & $1.89-3.25$ & $1.5 \pm 0.36$ & $0.66-1.84$ & $1.88 \pm 1.59$ & $0.30-5.82$ \\
\hline $\begin{array}{l}\text { Silver bream } \\
(\text { Blicca bjoerkna })\end{array}$ & $7.37 \pm 0.15^{b}$ & $7.26-7.47$ & $7.24 \pm 0.39$ & $6.96-7.51$ & $7.55 \pm 0.99$ & $6.85-8.25$ \\
\hline $\begin{array}{l}\text { European perch } \\
\text { (Perca fluvialitis) }\end{array}$ & $5.73 \pm 0.72^{\mathrm{c}}$ & $4.53-6.29$ & $7.99 \pm 0.36$ & $7.39-8.47$ & $6.63 \pm 0.71$ & $5.57-7.43$ \\
\hline
\end{tabular}

Legend: ${ }^{\text {a }}$ TBC in European eel samples was significantly less than in Silver bream and European perch samples $(\mathrm{P}<0.05)$

${ }^{\mathrm{b}}$ no significant differences between TBC in gill, skin and intestinal tract samples were observed in Silver bream gills, surface and intestinal tract samples $(\mathrm{P}>0.05)$

${ }^{\mathrm{c}}$ significant differences between TBC in gills, surface and intestinal tract were observed in European perch $(\mathrm{P}<0.05)$

${ }^{\mathrm{d}} \mathrm{CFU} / \mathrm{cm}^{-2}$ or $\mathrm{CFU} / \mathrm{g}^{-1}$

In general contamination of gills, skin and intestinal samples of eel was significantly less than in breams and perches $(\mathrm{P}<0.05)$. Eels in Latvia are introduced to lakes in elder or glass eel stage in the frame of eel breeding program and this could influence the contamination rates of eel microflora. TBC of eel gill, skin and intestinal samples is in accordance with previous reported study on number of bacteria presents on wild and farmed fish from cold and unpolluted environment (González et al., 1999). In contrast the Silver bream and European perch are wide spread in freshwater environment and belong to their native inhabitants in Latvia and therefore they can better reflect the situation with contamination of water source. In general contamination of skin, gills and intestinal tract for Silver bream and European perch was high in the present study. Nedoluha and Westhoff, 1997, Pullela et al., 1998 reported that bacteria load of freshwater fish depends on environmental influences and on type of fish production system. Thus, the high level of contamination of gills, intestinal tract and especially skin could be linked to contamination from outside environment.
Broad differences in TBC in freshwater fishes were reported previously and the number of TBC in skin samples was from 0.03 CFU.g ${ }^{-1}$ in carps in fish farms in Slovakia up to $10^{7} \mathrm{CFU}_{\mathrm{g}}{ }^{-1}$ in Rainbow trout skin samples in fish farm in Turkey (Andreji et al., 2006, Diler et al., 2000). Also number of TBC in gut was higher than $8.5 \times 10^{6} \mathrm{CFU}^{-1}{ }^{-1}$ in Mahmoud et al., 2004 study, however number in the intestinal content of stipped bass and salmonids could be $>10^{8} \mathrm{CFU}_{\mathrm{g}}{ }^{-1}$ that is agreement with our results (González et al., 1999).

Enterobacteriaceae was not detected on European eel, but was present in Silver bream and European perch skin samples. Number of Enterobacteriaceae in gills were ranged from 0.7 up to $5.78 \log \mathrm{CFU}^{-1}{ }^{-1}$, there the highest Enterobacteriaceae count was identified in European perch, but the lowest - in European eel samples. Number of Enterobacteriaceae count in skin and intestina tract was from 4.91 to $7.12 \log$ CFU.cm ${ }^{-2}$ and from 0.70 to $7.47 \log$ CFU.g ${ }^{-1}$, respectively, there the wide range in Enterobacteriaceae count among the European perch samples was observed (Table 2). 
Table 2 The number of Enterobacteriaceae count in freshwater fish gills, skin and intestinal tract

\begin{tabular}{|c|c|c|c|c|c|c|}
\hline \multirow{3}{*}{ Fish species } & \multicolumn{6}{|l|}{ Sampling site } \\
\hline & \multicolumn{2}{|c|}{ Gills } & \multicolumn{2}{|c|}{ Skin } & \multicolumn{2}{|c|}{ Intestinal tract } \\
\hline & Mean $\pm \mathrm{SD}^{\mathrm{d}}$ & Range & Mean \pm SD & Range & Mean \pm SD & Range \\
\hline $\begin{array}{l}\text { European eel } \\
\text { (Anguilla anguilla) }\end{array}$ & $1.4 \pm 0.51^{\mathrm{a}}$ & $0.7-2.11$ & $0 \pm 0.00$ & 0 & $2.43 \pm 2.44$ & $0.70-4.15$ \\
\hline $\begin{array}{l}\text { Silver bream } \\
\text { (Blicca bjoerkna) }\end{array}$ & $4.93 \pm 0.4^{b}$ & $4.9-4.97$ & $5.48 \pm 0.8$ & 4.91-6.04 & $6.04 \pm 1.26$ & 5.14-6.93 \\
\hline $\begin{array}{l}\text { European perch } \\
\text { (Perca fluvialitis) }\end{array}$ & $4.68 \pm 0.79$ & $3.8-5.78$ & $7.07 \pm 0.11$ & $6.95-7.12$ & $5.70 \pm 1.28$ & $3.83-7.47$ \\
\hline
\end{tabular}

${ }^{a}$ Number of Enterobacteriaceae in European eel samples was significantly less than in Silver bream and European perch samples (P<0.05)

${ }^{\mathrm{b}}$ Number of Enterobacteriaceae of skin samples was significantly higher in European perch than in Silver bream $(\mathrm{P}<0.05)$, but there were no differences in number of Enterobacteriaceae between gills and intestinal tract samples of European perch than in Silver bream $(\mathrm{P}>0.05)$

${ }^{\mathrm{d}} \mathrm{CFU} / \mathrm{cm}^{-2}$ or $\mathrm{CFU} / \mathrm{g}^{-1}$

Regarding to number of Enterobacteriaceae count of gills, skin and intestina samples of eel it was significantly less in eels than in bream and perch $(p>0.05)$ similar to number of TBC and the explanation of overall goof microbiology quality of ells in comparison with perch and bream could be their introduction to freshwater environment under the breeding program. In general number of Enterobacteriacea count of ells in the present study is in agreement with previously reported on wild and farmed fish from cold and unpolluted environment (González et al., 1999). An Enterobacteriaceae genus serves as a valuable indicator of hygienic status of the environment and products, related to hygiene and environmental contamination. High number of Enterobacteriaceae count in gills and intestinal and especially in skin samples indicates on contamination possibilities from outside environment. It is important to point out that increased number of Enterobacteriaceae count along with TBC may reflect the contamination from outside environment and possible consequences for environment and for fish consumers. Results on Enterobacteriaceae count in the present study were higher than the previously reported by González et al., 1999 in Spain for wild and farmed fish ranged from $1.00 \times 10^{1}$ CFU.g ${ }^{-1}$ to $4.86 \times 10^{4}$ CFU.g ${ }^{-1}$ and by Su et al., 2011 in China fish farms ranged from $3.3 \times 10^{3} \mathrm{CFU}_{\mathrm{g}}{ }^{-1}$ to $4.4 \times 10^{4}$ CFU.g ${ }^{-1}$. Skin was the most contaminated with coliforms in tilapia samples in Junior et al., 2014 study, who linked this to contamination of fish skin after fishing.

Salmonella spp. and $Y$. enterocolitica were not isolated from fish samples in the present study, while one sample of European perch was found to be $L$. monocytogenes positive (Table 3 ).

Table 3 Prevalence of Salmonella spp., Listeria monocytogenes and Yersinia enterocolitica in freshwater fish samples

\begin{tabular}{|c|c|c|c|}
\hline Fish species & Salmonella spp. & Listeria monocytogenes & Yersinia enterocolitica \\
\hline & $\begin{array}{c}\text { No. of positive samples/ No. of } \\
\text { samples }(\%)\end{array}$ & $\begin{array}{c}\text { No. of positive samples/ No. of } \\
\text { samples (\%) }\end{array}$ & $\begin{array}{c}\text { No. of positive samples/ No. of } \\
\text { samples }(\%)\end{array}$ \\
\hline $\begin{array}{l}\text { European eel } \\
\text { (Anguilla anguilla) }\end{array}$ & $0 / 11(0)$ & $0 / 11(0)$ & $0 / 11(0)$ \\
\hline $\begin{array}{l}\text { Silver bream } \\
\text { (Blicca bjoerkna) }\end{array}$ & $0 / 3(0)$ & $0 / 3(0)$ & $0 / 3(0)$ \\
\hline $\begin{array}{l}\text { European perch } \\
\text { (Perca fluvialitis) }\end{array}$ & $0 / 17(0)$ & 1/ 17 (6) & $0 / 17(0)$ \\
\hline Total & $0 / 31(0)$ & $0 / 31(3)$ & $0 / 31(0)$ \\
\hline
\end{tabular}

Absence of pathogenic bacteria in eel and bream indicates that fish are safe for consumption, while presence of $L$. monocytogenes in freshwater fish raise public health concerns. Salmonella was not isolated from freshwater fishes in studies across Europe and this is in agreement with our results (Davies et al., 2001, Andreji et al., 2006, Hudecová et al., 2010, Papadopoulos et al., 2010). Salmonella spp. can enter water sources with polluted and natural water related to human, wild and domestic animal activity. The high prevalence of Salmonella in fish was reported previously in Asia and Africa and usually is related to unsatisfactory hygienic condition of water sources and subsequently contamination of fish during placement on market (Budiati et al., 2013).

Our findings on the presence of $L$. monocytogenes in perch indicate that pathogen is distributed in aquatic environment in Latvia. L. monocytogenes is a natura inhabitant of water sources and can contaminate fish form sediment and outside environment and occasionally can contaminate fish and fish products. The prevalence of L. monocytogenes in previous studies in fish in Europe ranged from $0 \%$ in France, Portugal and Greece to $10 \%$ in Great Britain (Davies et al., 2001, Papadopoulos et al., 2010) and is in line with our results.

$Y$. enterocolitica was frequently isolated from water and terrestrial ecosystems and can be isolated also from fish (Velázquez et al., 1996). However in study of Davies et al., 2001 Y. enterocolitica was not found in fish samples from France, Great Britain and Portugal that is in agreement with our study.

In conclusion microbiological quality of bream and perch tested make these fishes unsuitable for consumption and therefore recreational fishing practice in Latvia and measures for prevention of cross-contamination at consumer level should be evaluated.

\section{CONCLUSION}

Microbiological quality of ells in the present study was the best comparing with bream and perch inhabiting the same lake and this finding may be attributed to different nature and biology of all fish species inhabiting Latvian freshwater sources.
L. monocytogenes is present in fish and therefore in aquatic environment in Latvia and this finding indicate that possible transmission of pathogen between environment and fish consumers exists.

Microbiological quality of perch and breams obtained from fishermen was not satisfactory and make fish unfit for human consumption therefore recreational fishing practice should be evaluated in order to prevent cross-contamination possibilities and to minimize the public health concerns.

Acknowledgments: This study was conducted within the ESF project No. 2013/0016/1DP/1.1.1.2.0/13/APIA/VIAA/055 „Iekšējo ūdeņu zivju resursu ķīmiskā un bioloğiskā piesārṇojuma pētniecības grupas izveide’".

\section{REFERENCES}

ANDREJI, J., STRANAI, I., KAČANIOVÁ, M., MASŚANYI, P., VALENT,M 2006. Heavy metals content and microbiological quality of Carp (Cyprinus carpio, L.) muscle from two Southwestern Slovak fish farms. Journal of Environmental Science and Health Part A, 41(6), 10711088. http://dx.doi.org/10.1080/10934520600620295.

BUDIATI, T., RUSUL, G., WAN-ABDULLAH, W.N., ARIP, Y.M., AHMAD R., THONG, K.L. 2013. Prevalence, antibiotic resistance and plasmid profiling of Salmonella in catfish (Clarias gariepinus) and tilapia (Tilapia mossambica) obtained from wet markets and ponds in Malaysia. Aquaculture, 372-375, 127 132. http://dx.doi.org/10.1016/j.aquaculture.2012.11.003DAVIES, A.R., CAPELL, C., JEHANNO, D., NYCHAS, G.J.E., KIRBY, R.M. 2001. Incidence of foodborne pathogens on European fish.

Food Control, 12(2), 67-71. http://dx.doi.org/10.1016/S0956-7135(00)00022-0

DILER, O., ALTUN, S., CALIKUSU, F., DILER, A. 2000. A study on qualitative and quantitative bacterial flora of the rainbow trout (Oncorhynchus mykiss) living in different fish farms. Turkish Journal of Veterinary and Animal Sciences, 24, 251-259.

GONZÁLEZ, C.J., LÓPEZ-DÍAZ, M.T., GARCÍA-LÓPEZ, M.L., PRIETO, M., OTERO, A. 1999. Bacterial microflora of wild brown trout (Salmo trutta), wild 
pike (Esox lucius), and aquacultures rainbow trout (Oncorhynchus mykiss), Journal of Food Protection, 62(11), 1270-1277.

HUDECOVÁ, K., BUCHTOVÁ, H., STEINHAUSEROVÁ, I. 2010. The effects on modified atmosphere packaging on the microbiological properties of fresh common carp (Cyprinus carpio). Acta Veterinaria Brno, 79, 93-100. http://dx.doi.org/10.2754/avb201079S9S093

JUNIOR, P.G., ASSUNÇÃO, A.W.A., BALDIN, J.C., AMARAL, L.A. 2014

Microbiological quality of whole and filleted shelf-tilapia. Aquaculture, 433 196-200. http://dx.doi.org/10.1016/j.aquaculture.2014.06.015

LATVIJAS STATISTIKA. 2013. http://www.csb.gov.lv/en/notikumi/householdexpenditure-food-monthly-comprises-lvl-55-capita-39101.html. Accessed on 22 October, 2014.

LATVIJAS VIDES, GGEOLOĢIJAS UN METEOROLOĢIJAS CENTRS. 2014. http://www.meteo.lv/hidrologija-datu-meklesana/?nid=466. Accessed on 24 October, 2014.

MAHMOUD, B.S.M., YAMAZAKI, K., MIYASHITA, K., IL-SHIK, S., DONG-SUK, C., SUZUKI, T. 2004. Bacterial microflora of carp (Cyprinus carpio) and its shelf-life extension by essential oil compounds. Food Microbiology, 21, 657-666. http://dx.doi.org/10.1016/j.fm.2004.03.001

MIETTINEN, H., WIRTANEN, G. 2006. Ecology of Listeria spp. in a fish farm and molecular typing of Listeria monocytogenes from fish farming and processing companies. International Journal of Food Microbiology, 112(2), 138146. http://dx.doi.org/10.1016/j.ijfoodmicro.2006.06.016

NEDOLUHA, P.C., WESTHOFF, D. 1997. Microbiology of stripped bass grown in three aquaculture systems. Food Microbiology, 14(3), 255-264. http://dx.doi.org/10.1006/fmic.1996.0095

PAPADOPOULOS, T., ABRAHIM, A., SERGELIDIS, D., KIRKOUDIS, I., BITCHAVA, K. 2010. Prevalence of Listeria spp. in freshwater fish (Oncorhynchus mykiss and Carassius gibelio) and the environment of fish markets in Northern Greece. Journal of the Hellenic Veterinary Medical Society, $15-22$.

PULLELA, S., FERNANDES, C.F., FLICK, G.J., LIBEY, G.S., SMITH, S.A., COALE, C.W. 1998. Indicative and pathogenic microbiological quality of aquacultures finfish grown in different production systems. Journal of Food Protection, 61(2), 205-210.

RIBEIRO, R.V., REIS, E.M.F., REIS, C.M.F., FREITAS-ALMEIDA, A.C., RODRIGUES, D.P. 2010. Incidence and antimicrobial resistance of enteropathogens isolated from an integrated aquaculture system. Letters in Applied Microbiology, 51(6), 611-618. http://dx.doi.org/10.1111/j.1472765X.2010.02946.X

SU, H.-C., YING, G.-G., TAO, R., ZHANG, R.-Q., FOGARTY, L.R., KOLPIN, D.W. 2011. Occurrence of antibiotic resistance and characterization of resistance genes and integrons in Enterobacteriaceae isolated from integrated fish farms in south China. Journal of Environmental Monitoring, 13, 3229-3236. http://dx.doi.org/10.1039/C1EM10634A

VELÁZQUEZ, L.C., ESCUDERO, M.E., GUZMÁN, A.M.S. 1996. Prevalence of Yersinia enterocolitica in hake (Merluccius hubbsi) fillets. Journal of Food Protection, 59(7), 781-783.

YÜCEL, N., BALCI, Ş. 2010. Prevalence of Listeria, Aeromonas, and Vibrio species in fish used for human consumption in Turkey. Journal of Food Protection, 73(2), 380-384. 